\title{
Entrepreneurial Barriers that are Confronted by Entrepreneurs Living with Physical Disabilities: A
} Thematic Analysis

\author{
*Eugine Tafadzwa Maziriri ${ }^{1}$, Welcome Madinga ${ }^{2}$, Thobekani Lose ${ }^{3}$ \\ ${ }^{1}$ School of Economic and Business Sciences, University of the Witwatersrand \\ ${ }^{2}$ Department of Marketing, Nelson Mandela Metropolitan University \\ ${ }^{3}$ Department of Logistics, Vaal University of Technology, South Africa \\ *euginemaziririri@yahoo.com
}

\begin{abstract}
Living with a physical disability can interfere with an individual's ability to participate actively in economic and social life. It is imperative to comprehensively understand the entrepreneurial barriers hindering the development of entrepreneurs living with physical disabilities. In spite of the increasing research on entrepreneurship, there seems to be a paucity of studies that have investigated the entrepreneurial barriers that are faced by entrepreneurs living with physical disabilities in South Africa. This study set out to explore the entrepreneurial barriers that are confronted by entrepreneurs living with physical disabilities. In this study, data were collected within the Sebokeng Township, which is an African township located in the Vaal Triangle, south of Johannesburg in South Africa. A qualitative research approach was used to collect data for the study. The researchers gathered qualitative data by means of semi-structured face-to-face interviews and focus groups. The analysis of the qualitative data was conducted through the use of thematic analysis. The themes that emerged from the findings include lack of equipment and machinery, discrimination, business networking, hardships in obtaining start-up capital, knowledge of support centres for entrepreneurs living with physical disabilities, and lack of education and training. Each theme was discussed individually, followed by substantiating quotes. Most respondents stressed that the barriers they face hinder the survival and growth of their ventures. The paper suggested that in order to help entrepreneurs living with physical disabilities, the South African government must formulate some schemes that are most necessary for their improvement and betterment of their life.
\end{abstract}

Keywords: Entrepreneurship, entrepreneurs, physical disabilities, barriers

\section{Introduction}

Entrepreneurship has been recognized as one of the tools that drive the economy of a country (Chell et al., 2016; Maziriri \& Madinga, 2016; Gree \& Thurnik, 2003). In addition, entrepreneurship is viewed as a process of creating something new with value by devoting the necessary time and effort; assuming the accompanying financial, psychic and social risks; and receiving the resulting rewards of monetary satisfaction, personal satisfaction and independence (Chinomona, Maziriri \& Moloi, 2014; Stokes, Wilson \& Mador, 2010; Hisrich \& Peters, 2002). Nchu, Tengeh and Hassan (2015) as well as 'Maziriri and Madinga (2016:1)' indicate that 'entrepreneurship is a significant component of the solution to South Africa's development issues'. 'Given the failure of the formal and public sector to absorb the growing number of job seekers in South Africa, increasing attention has focused on entrepreneurship and new firm creation and its potential for contributing to economic growth and job creation' (Maziriri \& Madinga, 2016; Wongnaa \& Seyram, 2014; Fatoki, 2014; Fatoki, 2010:87). Maziriri \& Madinga (2016:1) as well as Martins \& Couchi (2004) points out 'that in order to promote entrepreneurship, it is imperative to understand entrepreneurial barriers that affect entrepreneurs'. Barriers are not the same for all persons in society (Maziriri \& Madinga, 2016; Mauch, Mutengezanwa \& Damiyano, 2014; Martins \& Couchi, 2004). Although some obstacles are common to all people, some groups find specific obstacles, namely women, young people, people with disabilities, ethnic minorities, unemployed and people living in rural or distressed areas (McCann \& Ortega-Argiles, 2016; Maziriri \& Madinga, 2016; Mauch, Mutengezanwa \& Damiyano, 2014; Martins \& Couchi, 2004). Renko, Harris and Caldwell (2015) is of the view that entrepreneurship has many benefits for people with disabilities including increased independence, the ability to support themselves financially, the ability to set their own schedule and reduction of transportation problems if they are based at home. Moreover, entrepreneurship has come to be considered an important tool in poverty alleviation and increased empowerment of people with disabilities, but the prejudice they encounter creates barriers (Maziriri \& Madinga, 2016; Falch \& Hernaes, 2012; Maja, Mann, Sing, Steyn, \& Naidoo, 2011). Therefore, this study explores the entrepreneurial barriers that are confronted by entrepreneurs living with physical disabilities. 
Sebokeng Township: This study targets to collect data that can be useful in the development of entrepreneurs living with physical disabilities within the Sebokeng Township of South Africa. A geographical map of the Sebokeng Township is presented in Figure 1.

Figure 1: Sebokeng Township

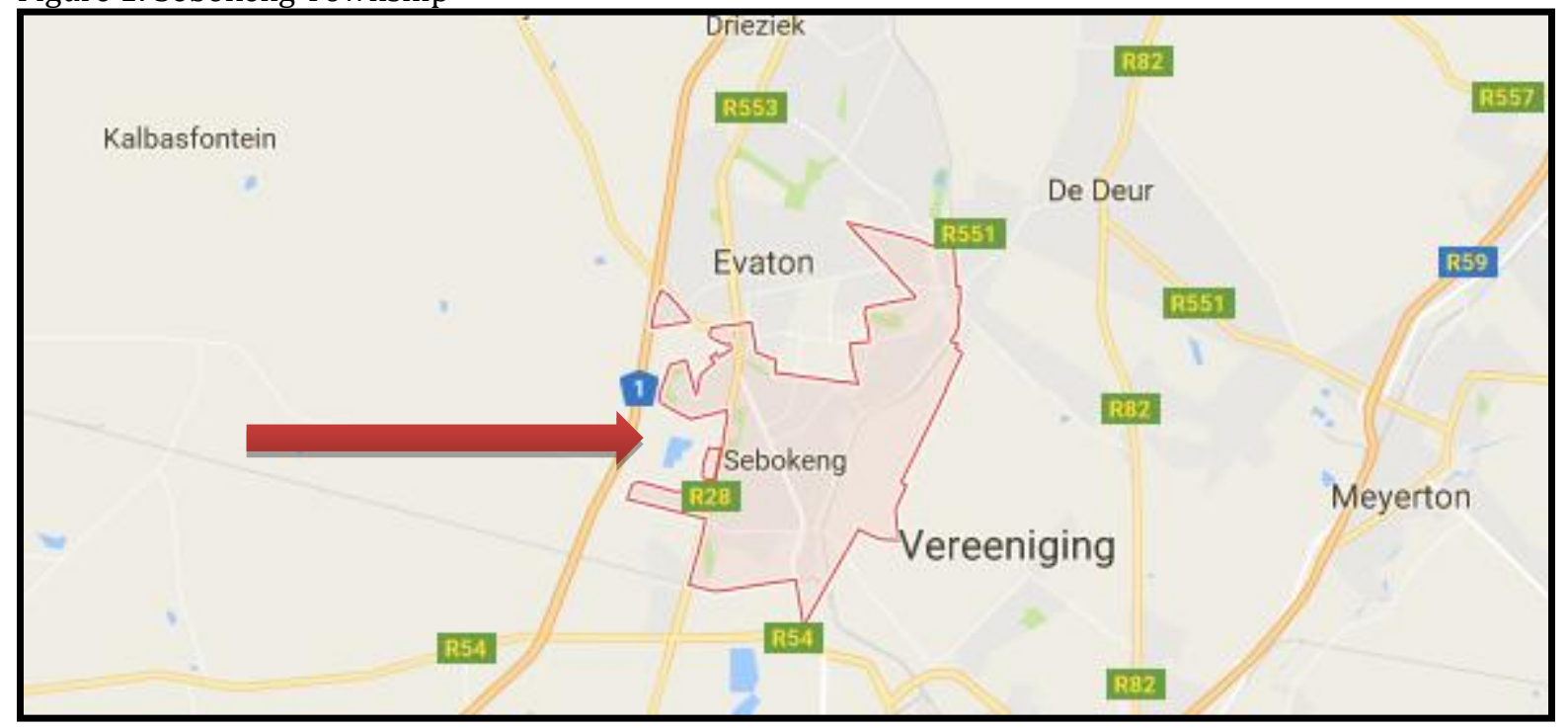

Source: Imagery (C2016, Google, DigitalGlobe, DigiGlobe, Map data (C2016 AfriGIS (Pty) Ltd., viewed 23 July 2016, from https://www.google.co.za/maps/place/Sebokeng/

According to Rueedi (2015:395), 'Sebokeng Township is an African township in the Vaal Triangle south of Johannesburg'. In addition, the Sebokeng Township is a micro-cosmos of the semi-industrialised, urbanized world and the living conditions in this area are almost identical to those of other blacks in other townships in South Africa (Mazibuko, 1993:2). Masitha faht senoz tnereffid otni dedivid si gnekobeS taht tuo stniop (2001:23 era senoz emos, elpmaxe roF .scitsiretcarahc tnereffid ssessop sevlesmeht ni occupied by relatively affluent people while others are characteristically poor. Each zone is very big, probably comprising more than 2000 households (Masitha, a sa sruenerpertne emoceb ot detpo evah gnekobeS fo stnediser eht fo ynaM .(2001:23 ae fo snaemrning an income since 1994; before then, entrepreneurship was strongly discouraged by the Apartheid government preferring black men to work in the neighboring suburbs of Vereeniging, Vanderbijlpark and Meyerton as cleaners, garden workers as well as delivery boys (Show me South Africa, 2016). Moreover, the types of businesses run by residents range from formal businesses such as beauty shops, pubs, petrol garages and night clubs to informal, usually home-based businesses such as spaza shops, hair salons and shebeens (Show me South Africa 2016). Therefore, from the author's explanation, this clearly shows that there is entrepreneurial activity within the Sebokeng of South Africa.

Statement of the research problem: Shanimon and Hameedu (2014) state that individuals with disabilities make up an estimated $15 \%$ of the population. Recent estimates of the prevalence of disability in South Africa suggest that $13 \%$ of the total population are disabled, $5 \%$ of whom are severely disabled (Statistics South Africa 2015). Being disabled may turn into a competitive disadvantage when a disabled entrepreneur faces competition from non-disabled entrepreneurs (Maziriri \& Madinga, 2016; Mohammed \& Jamil, 2015; Mwangi, 2013; Roni \& Baines, 2012; Roni, 2009; Mersland, 2005). For example, they need to hire a person to carry merchandise instead of carrying it oneself, which lead to additional transportation costs and slower production (Maziriri \& Madinga, 2016; Mwangi, 2013). Similarly, in some cultures, because of prejudice and superstition, being disabled can also result in a marketing disadvantage because customers may not want to contract products or services from disabled entrepreneurs (Yamamoto, Unruh \& Bullis, 2015). In addition, disabled people are likely to face specific barriers to entering and sustaining entrepreneurship (Bakara, Mohamada, Abdullaha, Intan, Sulaimana \& Hanafiaha, 2016; Kitching, 2014). Dotson et al. (2013:2336) point out that 'the number of people with disabilities is expected to increase'. Kasperova (2011) points out that 'disabled people of the working age are more likely than non-disabled people to become self-employed and 
they are a 'forgotten minority' in entrepreneurship research'. Renko et al. (2015) and 'Maziriri and Madinga (2016:2)' also reveal that 'one person out of 10 has a disability, yet entrepreneurship literature remains silent on the contributions of this population'.

In South Africa, the barriers that entrepreneurs living with physical disabilities face have not been sufficiently studied and developed. Previous research has examined entrepreneurs in various contexts by focusing on entrepreneurial attributes of undergraduate business students (Farrington et al., 2012), barriers facing female entrepreneurs (Sauer \& Wilson, 2016), Obstacles to youth entrepreneurship in South Africa (Fatoki \& Chindoga, 2011), Immigrant entrepreneurship in South Africa (Fatoki 2014), What motivates entrepreneurs (Hefer, Cant \& Wiid, 2015), Challenges in operating micro-enterprises by African foreign entrepreneurs (Khosa \& Kalitanyi, 2014) and 'Challenges facing women entrepreneurs in the Gauteng province of South Africa' (Chinomona \& Maziriri, 2015:835). Therefore, this research study aims at investigating the barriers that are confronted by entrepreneurs living with physical disabilities within the Sebokeng Township of South Africa. Moreover, the study will also focus on the possible solutions to overcome the barriers.

Significance of the study: This research is of significance because it is potentially useful in the current hot topic of developing township economies. This is in line with Mdluli (2015:20), who is of the view that very little has been researched within the South African context particularly in township settings. In addition, 'Bongazana (2014:60)' also confirms that 'South African urban townships are playing a significant role in the South African economy'. More precisely, this study focused on Sebokeng Township entrepreneurs living with physical disabilities and these entrepreneurs are capable of growing their businesses through creative and innovative activities, speeding up structural changes in the economy and thereby making an indirect contribution to productivity. However, it is of paramount importance to understand the barriers encumbering the growth and development of entrepreneurs living with physical disabilities. Despite numerous studies that have been undertaken on entrepreneurship, it remains significant to investigate barriers that are confronted by entrepreneurs living with physical disabilities within the Sebokeng Township of South Africa.

Theoretical background: For investigating the entrepreneurial barriers that are confronted by entrepreneurs living with physical disabilities, this study adopts the empowerment theory as its theoretical framework because it offers value frameworks for promoting human empowerment, for example, entrepreneurs living with physical disabilities.

The empowerment theory: 'Budeli (2012:16)' stated that 'the empowerment theory is seen as one of the best in supporting the interests of people with disability'. Robbins, Chatterjee and Canda (1998) highlighted the aims of empowerment to provide conceptualisations of social stratification and oppression, identify the personal and political barriers and dynamics that maintain oppression, offer value frameworks for promoting human empowerment and liberation and identify practical strategies for overcoming oppression and achieving social justice and to build on people's strength, resilience and resources. Additionally, Robbins et al. (1998) wished for people with disability to realise their aspirations and strengths and also to engage themselves in actions that support their personal well-being and social justice. The empowerment theory acts as an agent of change in making communities learn to recognize conditions of inequality and injustice with the aim of taking action to increase the powers of those regarded as powerless (Budeli, 2012:16). From the authors' elucidations, it can be stated that the empowerment theory aims at assisting marginalized people. For example, entrepreneurs living with physical disabilities can take power and act effectively in gaining greater control, efficacy and social justice in changing their lives and their environment. If the empowerment theory is taken into account, it can improve the growth of the entrepreneurship field and stimulate entrepreneurial attitudes and activities of entrepreneurs living with physical disabilities in South Africa. The empowerment theory can assist entrepreneurs living with physical disabilities to be very active in their entrepreneurial ventures, thereby elevating their living standards.

\section{Literature Review}

In order to present a well-rounded picture in relation to the title of the study, the researchers reviewed the literature on what an entrepreneur is and what physical disability is. 
An Entrepreneur: According to Edelman et al. (2016), the word 'entrepreneur' comes from the French entreprendre, which translated roughly, means to set about or to undertake. Entrepreneurs are a unique group of people as they assume risk, manage the business' operations, reap the rewards of their success and bear the consequences of their failure (Duvenhage, 2013; Antonites \& Govindasamy, 2013:143; Henderson, 2002). The entrepreneur is seen as a person who gets things done and is an economic innovator (Van der Lingen \& Van Niekerk, 2015:119). In addition, Tehseen and Ramayah (2015) as well as 'Kitching (2014)' assert that 'an entrepreneur is an individual who develops and grows the businesses through creative and innovative activities by introducing new products or services and by improving the existing methods of production or service'. Dijkhuizen et al. (2016) as well as Maziriri and Madinga (2016) describe the entrepreneur as someone who sees gaps within the market environment and takes the advantage to fill the gap; thus, it is accepted that the entrepreneur takes more risks to increase personal interest to seize available opportunities (Marino et al., 2011; Certo, Moss \& Short, 2009). Although opinions vary as to what an entrepreneur is, the word normally carries the meaning of new ideas and creative development in the framework of large organizations (Morales et al., 2016).From the authors' elucidations on what an entrepreneur is it can be noted that an entrepreneur is an individual who sets up a business taking on financial risks in the hope of gaining profits.

Understanding physical disability: A disabled person is defined as a person with a physical, mental or sensory disability, including a visual, hearing or speech functional disability, which gives rise to physical, cultural or social barriers inhibiting him from participating at an equal level with other members of society in activities, undertakings or fields of employment that are open to other members of society (Mandipa, 2013; Viriri \& Makurumidze, 2014). In addition, because there are various types of disabilities, in this study the researchers mainly focused on those entrepreneurs who are physically disabled. The Physical Disability Council (2015) elucidates that physical disability is a limitation on a person's functioning, mobility, dexterity or stamina. According to Shuma (2011), people with physical disabilities experience dysfunctions, such as poor muscle control, weakness or fatigue; difficulty in walking, talking, seeing, speaking, sensing or grasping (because of pain or weakness); difficulty in reaching things; and difficulty accomplishing complex or compound manipulations (push and turn). A person may be born with a physical disability or acquire it later in life through accident, injury, illness or side effects of medical treatment (Physical Disability Council, 2015). Moreover, most people with physical disabilities have to rely on devices such as wheelchairs, crutches, canes or artificial limbs to achieve mobility (Shuma, 2011). Drawing from the authors' explanations it can be noted that physical disability is a restriction on a person's physical functioning, mobility, and stamina.

Entrepreneurial barriers that are confronted by entrepreneurs living with disabilities: The literature cites a number of constraints that entrepreneurs living with disabilities face in their daily lives. It is imperative to pinpoint and to understand the constraints faced by entrepreneurs living with disabilities in South Africa. Many disabled individuals face many obstacles that disallow them from participating effectively in the society and in their entrepreneurial businesses. The following are some of the challenges that entrepreneurs living with disabilities face.

Discrimination: Discrimination can be defined as distinguishing unfavourably or the detection of the difference between one thing and another (Maziriri \& Madinga, 2016; Chinomona \& Maziriri, 2015:840; Madipaka, 2014). According to Marumoagae (2012) 'discrimination against people with disabilities is one of the worst social stigmas that society has not been able to overcome'. Maja et al. (2011) point out that discrimination against people with disabilities is a result of negative attitudes, lack of knowledge and awareness. People with disabilities are regarded as people who cannot contribute to anything and are dependant and always wait to be helped (Uromi \& Mazagwa, 2015). Renko et al. (2015) explain that people without disabilities usually have negative impressions about people with disabilities, viewing them as inferior. These impressions can foster discrimination when entrepreneurs living with disabilities run their businesses as people without disabilities will be viewing them as inferior.

Access to start-up capital: Mauchi, Mutengezanwa and Damiyano (2014) state that lack of access to capital, credit schemes and the constraints of financial systems are regarded by potential entrepreneurs as main hindrances to business innovation and success in developing economies. Disabled people often experience difficulties financing new start-ups because of limited personal financial resources (savings, home 
ownership), which, in turn, is partly because of poor education, lower employment rates and the concentration of disabled employees in low-paid occupations; poor credit rating after long-term benefit receipt; disinterest/discrimination on the part of banks; and lack of accessible information on sources of grants and loans (Foster, 2010). Viriri and Makurumidze (2014) emphasised that access to capital and lack of customers as the two major barriers to self-employment by people with disabilities.

Lack of entrepreneurial education and skills: South Africa does not suffer from a lack of creative spirit, but rather a lack of business education and entrepreneurial skills that can empower individuals in an enabling environment (Maziriri \& Madinga, 2016; Steenekamp, Vander-Merwe \& Athayde, 2011; Burger, Mahadea \& Neill, 2004). Choto, Tengeh and Iwu (2014) as well as Xaba and Rankhumise (2014) elucidate that 'there is a gap in entrepreneurial training, suggesting that the education systems in South Africa do not encourage entrepreneurship as a career; entrepreneurship is seen as something that people can do when they fail to secure a job and when they do not have a profession'. Furthermore, Choto et al. (2014) indicated that 'lack of education and training was a major inhibitor of entrepreneurial growth in the economy'. Disabled people often lack specialist business management, legal and financial expertise because of limited relevant education and employment experience and might feel at a disadvantage (Enabled4Enterprise, 2008).

Ways to address the barriers that hinder entrepreneurs living with physical disabilities: The following are some of the ways that can be initiated in order to overcome the barriers faced by entrepreneurs living with physical disabilities.

Education and training: The key to success in establishing a culture of entrepreneurship in South Africa is education (Chimucheka, 2014; Isaacs et al., 2007). Entrepreneurship education is said to be very important in the nurturing of the entrepreneur (Kitching, 2014; Parhankangas \& Ehrlich, 2014). Raposo and Do Paço states that "entrepreneurship education seeks to propose people, especially young people, to be responsible, as well as enterprising individuals who became entrepreneurs or entrepreneurial thinkers who contribute to economic development and sustainable communities". Disabled entrepreneurs need training in terms of business plan preparation, strategic planning, decision making, negotiation, pricing, market penetration, organisation and management, management of the workforce and handling of cash flow among other issues (Viriri \& Makurumidze, 2014). Literature confirms that skills training and business education have a positive effect on enterprise performance (Morales et al., 2016; Maziriri \& Madinga, 2016; Chinomona \& Maziriri, 2015:842; Mpofu \& Shumba, 2013; Akanji, 2006). It is acknowledged that the exploitation of entrepreneurial opportunity depends on the entrepreneur's level of education, skills or knowledge acquired through work experience, social network and credit (Kitching, 2014; Parker, Caldwell \& Renko, 2014). Dawson and Henley (2012) point out that any entrepreneurship training program for people with disabilities should be delivered in partnership between people with different areas of knowledge and expertise, both from the disabled and non-disabled communities. According to Hessels, Gelderen and Thurik (2015), in order for this collaboration to succeed, all parties involved must understand the successful strategies for business planning and business ownership for people with disabilities. Hessels et al. (2015) further argued that this common basis of understanding would facilitate the collaborative efforts of the self-employment program, its human services and economic development partners and the people with disabilities who seek self-employment as their means for employment and economic growth. From the authors' elucidations, it can be pointed out that obtaining the appropriate skills, information about running an entrepreneurial venture and forming partnerships individuals with individuals from different areas of knowledge and expertise can help entrepreneurs living with disabilities to successfully run their business without any hurdles.

Empowerment for entrepreneurs living with disabilities: Moyo and Francis (2010) defines empowerment as 'an ongoing process in which people see themselves as having the capacity and right to act and influence the circumstances they find themselves in'. People with disabilities in actual fact need to be empowered and their life's 'requisites need to be taken care of'. Hence, with the government intervention by providing benefits of equal rights, the disabled would also be able to contribute to the economic growth of a country (Osman et al., 2014). According to Mpofu et al. (2011), people with disabilities and their families need to be empowered and trained to take care of their needs in every sphere of their life. One of the ways for effective economic empowerment for the disabled is by encouraging and supporting them in activities of their communities such as entrepreneurship. Entrepreneurship is significant contributing factor towards economic 
growth for both developed and developing countries. The involvement of people with disabilities in the entrepreneurial activity will help to improve their quality of life as well as make the Millennium Development goal of most developing countries achievable by reducing 50\% of the poverty rate by 2015 (Mpofu \& Shumba, 2013; Rahim et al., 2014).

Financial support: Entrepreneurs living with disabilities can gain financial support in various ways. Financial support might take the form of grants, loans, subsidized loans or loan guarantees to credit providers, tax credits and exemption from business registration fees (Wilson, 2016; Maziriri \& Madinga, 2016; Greve, 2009). Pergelova \& Angulo-Ruiz (2014) explains that government financial support through loans and equity can allow new ventures not only to accumulate assets and to obtain access to critical resources (e.g. technology, licenses and equipment), but also to invest in internal firm processes such as employee training, as well as in activities that would bring market acceptance such as building a brand name. Kitching (2014) is of the view that financing might be tied to purchasing specific equipment, skills training or attendance at events such as trade fairs or exhibitions (e.g. 12 Spain 2012) or to the development and application of assistive technologies. Chinomona and Maziriri (2015:841) point out that 'most applicants do not know what is expected of them when making application to financial institutions for assistance and the Department of Trade and Industry has a business referral and information network website to assist entrepreneurs in this area'. The institutions that have been outsourced to act on behalf of the Department of Trade and Industry are the Khethani Business Finance (Khula RFI), Landelike Onwikkelings Maatskappy, Nations Trust (Khula RFI) and the New Business Finance (Chinomona \& Maziriri, 2015:841).

Support from the government: The quote by Albrecht (1997): The civility of a country is judged by how it treats its children, its persons with disabilities, and its poor and elderly citizens', clearly shows that a country like South Africa can be perfectly considered as a good nation when it gratifies its children, people with disabilities and the poor and elderly citizens. The government of South Africa can take an intervention in various ways to assist entrepreneurs living with disabilities. According to Kitching (2014), policy-makers need to consider methods of delivering advice and support to disabled entrepreneurs. Obaji and Olugu (2014) claim that the government needs to enact policies that would be user-friendly to the entrepreneur. Furthermore, Oni and Daniya (2012) explain that the governments of most countries, especially developing countries, have in the past invested much of their efforts and resources in establishing policies intended to uplift entrepreneurship. For instance, in Nigeria, different administrations at numerous times have geared their efforts towards developing their entrepreneurship efforts and several developmental and financial assistance instruments were employed (Oni \& Daniya 2012). According to Salem (2014), the kingdom of Saudi Arabia in 2010 established a 10-year entrepreneurship effort and innovation and the intention was a strategy to put the Kingdom at the equal pedestal with high-economic competitive nations globally. The Brazilian entrepreneurship movement has got established very fast as a result of government policies geared towards developing the low-tech businesses as well as high technological-oriented firms (Nchu et al., 2015). Hence, the South African government can introduce policies and strategies similar to those of Nigeria, the kingdom of Saudi Arabia and Brazil in support of entrepreneurs, especially those living with disabilities in the republic of South Africa.

\section{Methodology and Design}

Study design: The research design that was adopted for this study was essentially exploratory in nature. The exploratory approach, in this case, was expected to provide the opportunity to unravel the nature of the physically disabled entrepreneurs' experiences and perspectives, of which little is known. The rationale for using exploratory research was to obtain a richer understanding of the experiences relating to the challenges experienced in the pursuance of their businesses. Essentially, and in keeping with the approach stated above, during the interview, participants were given the opportunity to describe their experiences and challenges in terms of factors they perceived to be hindering factors in the operation of their businesses. The researchers adopted a qualitative approach that was descriptive and exploratory in nature. The reason for adopting qualitative methodology was the need to understand the experiences of business owners and how they dealt with their daily business operations to ensure success (Flyvbjerg, 2011). Chinomona et al. (2014) point out that in a qualitative research paradigm, the researcher builds a complex, holistic picture; analyses words; reports detailed views of informants; and conducts the study in a natural setting. In addition, Leedy and 
Ormrod (2010) as well as Xaba and Rankhumise (2014:184) explain that 'the qualitative research method is appropriate when the researcher is trying to understand a new phenomenon in a particular situation rather than trying to establish a relationship between two or more variables'.

Research paradigm: According to Sefotho (2015), 'qualitative research is fundamentally phenomenological and is referred to as interpretive phenomenological research'. Hammond, Howarth and Keat (1991:1) refer to phenomenology as the 'description of things as one experiences them, or of one's experiences of things'. The aim of phenomenology is to bring out the 'essences' of experiences or appearances (phenomena), to describe their underlying 'reason' (Pivcevic, 1970). Phenomena are fundamentally important for qualitative researchers (Sale, Lohfeld \& Brazil, 2002). They must seek understanding of people's lived experiences as phenomena for inquiry (Sefotho, 2015). Therefore, in this study, the researchers identified phenomenology as the suitable research paradigm for the study as it seeks to bring out the barriers that are encountered by physically disabled entrepreneurs in their daily lives.

Unit of analysis: Antonites and Kliphuis (2011) define a unit of analysis as the main body that is being analysed in a study. In this study, the unit of analysis is the South African entrepreneur living with a physical disability.

Population of the study: In research, population refers to the aggregate of all the units that are eligible to participate in a study (Creswell \& Plano, 2007:112; Salkind, 2012:95). In addition, a population is defined by Welman, Kruger and Mitchell (2011:53) as a group of entities with a common set of characteristics. In this study, the population of relevance will consist of all entrepreneurs living with physical disabilities within the Sebokeng Township of South Africa.

Sample size: A sample can be defined as a portion of a larger population (Dube, Roberts-Lombard \& Van Tonder, 2015:243). Roets (2013:36) defines sample size as the count of factors involved in the study. A sample size larger than 30 and less than 500 is appropriate for most research studies (Xaba \& Rankhumise, 2014; Choto et al., 2014:97). Therefore, this research study utilized 35 participants.

Sampling technique: Dahlberg and Mccaig (2010:175) assert that two methods exeunt for sampling, namely probability and non-probability sampling. As no register of entrepreneurs living with physical disabilities existed in the Sebokeng Town, a snowball sampling strategy was used to identify entrepreneurs living with physical disabilities. Snowballing sampling is a non-probability sampling method in which the researcher approaches one member and the member in turn refers the researcher to another member (Choto et al., 2014:97). Moreover, the snowball sampling method was the most appropriate method for this study as the researchers had few individuals to participate in the study who helped in identifying other participants who best matched the research (Choto et al., 2014:97).

Ethical considerations: Ethical issues are principles and guidelines that clarify the conditions under which the research will be conducted (Oates, Kwiatkowski \& Coulthard, 2010). Research respondents may be harmed physically or emotionally during data collection (Maziriri \& Madinga, 2016; Balfour, 2007; Strydom, 2005). Since the researchers' target population comprised entrepreneurs who are physically disabled, in this study there was the chance of triggering emotional harm or stress to the participants as the focus of the study is to find out what challenges the participants encounter in their business operations as physically disabled people. Being emotional and a possible cause of sadness may be brought up because of the fact that they are physically disabled. On the other hand, the study may have been experienced by the participants as a stress reliever as it may have given the participants a verbal outlet where they could express their feelings, needs, concerns and wishes with regards to their entrepreneurial businesses as disabled people. The researchers were responsible for making it clear to the respondents that there would be a possibility that the research could bring about change but that there would be no guarantee that change would occur. This research study act in accordance with the ethical standards of academic research, which among other things, is protecting the identities and interest of participants and assuring confidentiality of information provided by the participants. Participants gave their informed consent to this research and were informed beforehand about the reason and the nature of the investigation to ensure that participants were not misled. Despite all the 
above-mentioned precautions, it was made clear to the participants that the research was only for academic research purpose and their participation in it was absolutely voluntary. No one was forced to participate.

Semi-structured face-to-face interviews: For the purpose of this study, data were collected using semistructured face-to-face interviews. Interviewing is the predominant mode of data or information collection in qualitative research (Sobuce, 2012; Lord, 2009; Cooke, 2009; Greeff, 2005; Taylor, 2005; Whitley, 2002). Interviews provide an avenue for generating data by talking to people about how they go about their day-by day dealings (Thompson, Bounds, \& Goldman, 2012:40). Semi-structured interviews were conducted with entrepreneurs living with physical disabilities. Semi-structured interviews are defined as interviews organized around areas of particular interest, while still allowing considerable flexibility in scope and depth (Ncanywa, 2014; Stofberg, 2009; Greeff, 2005). In addition, Maziriri and Madinga (2015) indicated that such interviews combine particular questions (to get forth the foreknown information) and open-ended questions (to provoke unanticipated types of information). Furthermore, the semi-structured format also permits and encourages the investigator to interject with added questions as appropriate. In this study, data were gathered by interviewing the participants at their respective business premises in the Sebokeng Township and the nature of the businesses for these participants comprised carpentry workshops, fast food outlets, beauty shops, pubs, metal workshops and hair salons. The interviews spanned approximately $20 \mathrm{~min}-30$ min each. In order to increase the reliability of the answers, all the interviews were recorded, where possible, on a digital voice recording device. Six participants refused to be recorded and only allowed note taking of their challenges as physically disabled entrepreneurs. The answers given by the interviewees were carefully noted on a hard copy; transcriptions were proofread and matched to the audio tapes by the researchers. Finally, a total of 20 interviews were conducted with entrepreneurs who are physically disabled. The researchers felt it was enough but needed to further validate the findings with the data from focus groups.

Focus groups: The study conducted a focus group of 15 entrepreneurs consisting of nine men and six women. Moloi et al. (2010) elucidate that focus group interviews as a research technique are described as a semi-structured group discussion, moderated by a discussion leader, held in an informal setting, with the purpose of obtaining information by means of group interaction on a designated topic. A focus group is an interview conducted by a trained interviewer among a small group of respondents (Chinomona \& Maziriri, 2015:843; Chinomona, Maziriri \& Moloi, 2014; Cooper \& Schindler, 2011). The researchers made use of focus groups because it brings the opportunity to obtain a large amount of data, to observe interaction and to obtain different views or perceptions of a topic in a limited period of time. Group discussions also provide direct evidence about similarities and differences in the participants' opinions and experiences (Babbie \& Mouton, 2007).

\section{Findings}

The discussion in this research paper is presented in line with the themes that arose from the focus group and interview transcripts. Thematic analysis is defined as a meticulous process of identifying, analyzing and reporting themes that emerge from a qualitative study (Muposhi, 2015:168; Muposhi, Dhurup \& Surujlal, 2015:230; Retief, 2009:42; Braun \& Clarke, 2006:79). Thematic analysis is regarded as the "foundational method for qualitative analysis" and was the chosen to formally commerce the analytical process given its suitability to the exploratory nature if the research (Apolloni, 2010:88). The major advantage of thematic analysis is that it is a logical process that allows the researcher to scrutinize interview transcripts comprehensively and glean all possible themes (Muposhi, 2015:168; Muposhi, Dhurup \& Surujlal, 2015:230; Glesne, 2011:187). The following framework indicates the main themes identified in the data sources. Each theme will be discussed individually, followed by substantiating quotes. Interpreted data will be compared with existing literature.

Theme 1-Lack of equipment and machinery: Lack of equipment and machinery emerged as one of the most important themes during interviews. The entrepreneurs living with physical disabilities indicated that lack of equipment and machinery hinders them from succeeding in their entrepreneurial businesses. Examples of entrepreneurial activities in the Sebokeng Township includes households furniture manufacturing that includes timber sawing, carpentry workshops for manufacturing chairs, non-chemical agricultural input activities, clothing and food manufacturing. However, participants (entrepreneurs living 
with physical disabilities) indicated that most of these entrepreneurial activities were meant for community members in general and were not tailored to meet their disabling conditions. Therefore, there would need proper equipment and machinery to support them in executing their entrepreneurial duties. Here are some of the comments they made:

'It becomes difficult for me to operate my carpentry business without proper equipment such as the wood processing machine, wood cutting machine, wood joining tool, wood planning tool as well as a carpenter's pincer. These tools and machinery make my life easier since I'm physically disabled.' [Jabulani, Male, Carpenter]

'...Since we are physically disabled I believe that the number one limiting factor for some of us is to have proper supporting tools and machinery to lighten the amount of work that needs to be done in our entrepreneurial businesses.' [Matthew, Male, Sculptor]

'...Because I am in a wheelchair,the best thing for me would be to have machinery for my business, so that I get on board with new machines that are designed with the user in mind and ultimately increasing the productivity of my business.' [Vusumuzi, Male, Welder, 26]

These sentiments are in line with works of Ngorora and Mago (2013:4) who investigated the challenges of rural entrepreneurship in South Africa. Their study's results revealed that some entrepreneurs especially those in constructed and welding bemoaned lack of equipment as a factor that is hindering many businesses from starting and even offering effective service.

Theme 2-Discrimination: Another recurring theme that emerged from interviews was that of discrimination. Conceptually, discrimination refers to a negative (push) factor that influences entrepreneurial intentions of the disabled (Johnmark \& Munene, 2016:2). In addition, Keene (2011:2) defines 'discrimination as is the denial of equal rights based on prejudices and stereotype'. In this study, most of the entrepreneurs living with physical disabilities expressed that they lack confidence as they experience a lot of discrimination. Here are some of the comments they made:

'I need answers as to why we have to go through such discrimination and humiliation just because we are physically disabled.' [Xolisile, Female, Jewellery designer, 24]

'We are always last in line for everything, we are not treated the same because of this stigma'. [Basetsana, Female, Hair dresser, 30]

'How does society ever expect us to make a living for ourselves, if this is its attitude?' [Dikeledi, Female, Cook, 29]

In addition, these results also refute the study conducted by Uromi and Mazagwa (2015) to 'investigate the challenges facing people with disabilities and possible solutions in Tanzania'. The results indicated that community members have a discriminative, inconsiderate and non-caring attitude towards people with disabilities.

Theme 3-Lack of business networking: Business networking is one of the dominant themes that emerged from interviews. The study's theme encompasses a socioeconomic business activity by which business people and entrepreneurs meet to form business relationships and to recognize, create, or act upon business opportunities, share information and seek potential partners for ventures. However, the majority of the participants acknowledged that they are not actively involved in business networking activities in the studied Sebokeng Township area. Solely because of their disabling condition, they experience negative attitudes from communities who view them as not competent and are unable to make and maintain sound relationships with non-disabled entrepreneurs:

'Most entrepreneurs who are not disabled exclude us from their business networking events just because we are physically challenged; this is because they recognized us as entrepreneurs who are very slow in their business operations.' [Howard, Male, Computer programmer, 24]

'Each time I attend business networking events people see my disfigurement and they wouldn't want to, or don't know how to, approach me.' [Peter, Male, 25]

'I have found business networking events to be a difficult and a daunting prospect because each time I attend a networking event I have seen some negative attitudes towards some of us who are physically disabled entrepreneurs.' [Terrence, Male, 34] 


\begin{tabular}{l} 
Journal of Economics and Behavioral Studies (ISSN: 2220-6140) \\
Vol. 9, No. 1, pp. 27-45, February 2017 \\
\hline \hline
\end{tabular}

These results are in line with literature. Vlachou (1997) confirms that 'persons with disabilities are excluded from various community activities on the grounds of their condition'. In addition, Viriri and Makurumidze (2014) also points out that 'disabled entrepreneurs are socially excluded, stigmatized and marginalized and consequently their network ties and cohesion in business circles are weak and frail'.

Theme 4-Hardships in obtaining start-up capital: Another theme that emerged from interviews was hardships in obtaining start-up capital. The majority of the participants attested that they experience some hardships in obtaining start-up capital, mostly when they seek help from financial institutions for loans. This reflected by the following statement:

'Commercial banks do not want to offer loans to entrepreneurs living with physical disabilities, for the reason that they are not confident in our competences to run businesses.' [Sandra, Female, 31]

These sentiments are in line with the literature. Mauchi, Mutengezanwa and Damiyano (2014) state that 'lack of access to capital, credit schemes and the constraints of financial systems are regarded by potential entrepreneurs as main hindrances to business innovation and success in developing economies'. Moreover, this finding concurs with that of Mwangi (2013:286) that 'the major problem that the physically challenged entrepreneurs experience is the start-up capital'.

Theme 5-Knowledge of support centres for entrepreneurs living with physical disabilities: Data from the study also reveal that participants were not aware of the government support centres or initiatives of supporting the businesses that are managed and operated by entrepreneurs living with physical disabilities. Only a few indicated that they had once got support from the government and went further to highlight that the government support they received was not enough to sustain them in running their entrepreneurial ventures. This view is aptly encapsulated in the following comments:

'I am not even aware of the available support organisation that may assist me in my business.' [Akhona, Female, 31]

'Ever since I become an entrepreneur the support I have received from the government is insufficient.' [Bongani, Male, 43]

These findings confirm what Chimucheka and Mandipaka (2015) found in their study that 'some small, medium and micro-enterprises are not aware of the government support or initiatives of supporting businesses'. In addition, Viriri and Makurumidze (2014) also found out that 'young people with disabilities were not aware of entrepreneurial policies in their country'. 


\section{Figure 1: Conceptual model}

\section{ENTREPRENEURIAL BARRIERS}

Lack of equipment and machinery

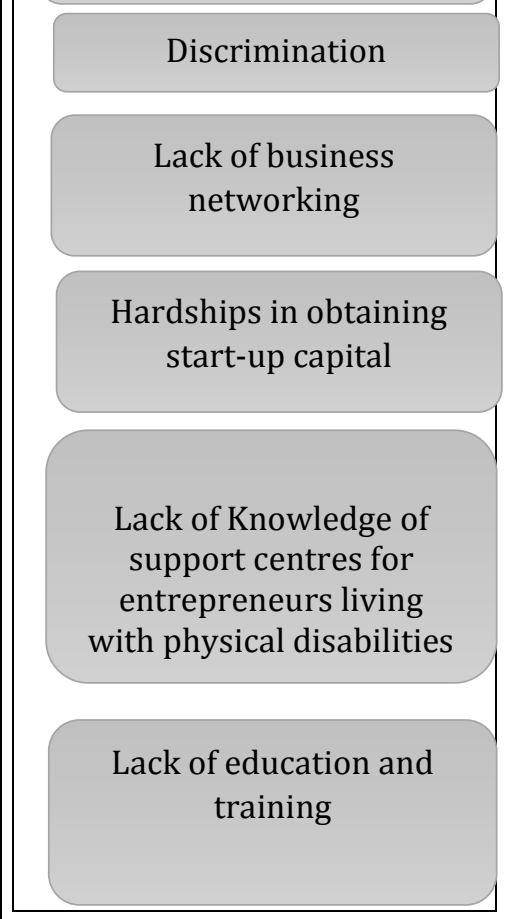

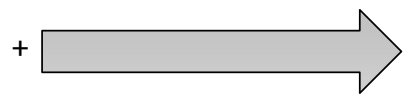
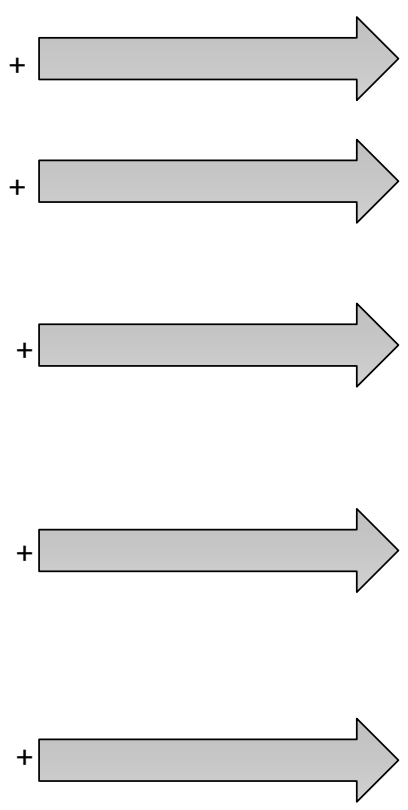

ENTREPRENEURIAL

FAILURE

\{Among entrepreneurs living with physical disabilities\}

Source: Authors own compilation

Theme 6-Lack of education and training: The final theme to emerge from interview transcripts is a lack of education and training. Education and training are expected to improve peoples' ability to take advantage of opportunities that can improve their well-being as individuals and be able to participate more effectively in the community and labor markets (Wairimu 2014). In this study, the participants indicated that lack of education and training is also a barrier hindering the success of their entrepreneurial businesses. This reflected in the following excerpts:

'We do not have adequate knowledge and teaching on how to manage various entrepreneurial businesses.' [John, Male, 33]

'I wish there are support structures in the Sebokeng Township that are willing to educate and train only entrepreneurs who are living with physical disabilities.' [Themba, Male, 35]

This finding accords with that in the literature, which states that education and training system is regarded as the number one limiting factor for entrepreneurship in South Africa (Herrington \& Wood 2003). In addition, Fatoki and Garwe (2010) also confirmed that entrepreneurship education is still one of the prime factors limiting the growth of the economy of South Africa. Moreover, the results of this study are in line with the works of Mpofu and Shumba (2013), who found out that that there is no entrepreneurial education designed to meet the needs of available targeting people with disabilities.

Conceptual Model: After thematic analysis of research data, a conceptual model was developed. Below is an illustration of the research conceptual model.

Above is an illustration of the research conceptual model of the current study. After analysis of themes observed in the study, it was found that entrepreneurial barriers (lack of equipment and machinery, 
discrimination, business networking, hardships in obtaining start-up capital, knowledge of support centres for entrepreneurs living with physical disabilities, and lack of education and training) influences entrepreneurial failure among entrepreneurs living with physical disabilities. Entrepreneurial failure is linked to unrewarding or ceased trading (Makhbul \& Hasun, 2011:117).

\section{Conclusion}

The main objective of this study was to investigate the entrepreneurial barriers that are confronted by entrepreneurs living with physical disabilities in the Sebokeng Township of South Africa. This study has looked at the keywords physical disability, entrepreneur and a disabled person and the objectives of the study have been identified. An extensive literature review has been undertaken to have an overview or to comprehensively understanding what an entrepreneur is and what physical disability is. In addition, the literature review also provided a rich theoretical base by giving an overview of the various entrepreneurial challenges that are confronted by entrepreneurs living with physical challenges as well as the ways to overcome those barriers. A qualitative methodology was used with the use of semi-structured interviews and focus groups. The study analysed the responses of the physically disabled entrepreneurs and identified the specific barriers faced by them in entrepreneurship. Most respondents stressed that the barriers they face hinder the survival and growth of their ventures. Moreover, it was found that entrepreneurs living with physical disabilities face barriers such as lack of equipment and machinery, discrimination, business networking, hardships in obtaining start-up capital, knowledge of support centres for entrepreneurs living with physical disabilities and lack of education and training.

Practical implications: The business world is ever-increasingly becoming competitive and to be a well established entrepreneur is an enormous challenge. The findings of this study are expected to have to provide fruitful implications to both practitioners and academicians. On the academic side, this study makes a significant contribution to the entrepreneurship literature by exploring on the entrepreneurial barriers that are confronted by entrepreneurs who are living with physical disabilities. On the practitioners' side, the key challenges that are confronted by entrepreneurs living with physical disabilities are clearly highlighted. This study therefore submits that entrepreneurs can benefit from the implications of these findings. For example entrepreneurs are ought to pay attention to the empowerment theory of build self confidence or to build engage in networking activities so as to learn from one another.

Recommendations: Based on the findings discussed in this paper, the following recommendations can be put forward to entrepreneurs living with disabilities and the government of South Africa. The key recommendations to the Government of South African include the following: Obaji and Olugu (2014) postulate that 'the government needs to enact policies that would be user friendly to the entrepreneur'. Thus, in order to help entrepreneurs living with physical disabilities, the South African government must formulate some schemes that are most essential for their improvement and betterment of their life. In addition, if entrepreneurs living with physical disabilities are supported by the South African Government with equipment (tools) and machinery, they would be successful in their entrepreneurial ventures. It is also important for the South African government to make every effort to improve the intellectual capacity among entrepreneurs living with physical disabilities and provide entrepreneurship education by expanding and strengthening tertiary education. There is the need for government to help ease the problem of access to start-up capital among entrepreneurs living with physical disabilities, especially those who are still at the introductory stage. In addition, the South African government should come up with a considerable dedicated fund for entrepreneurs living with physical disabilities to support their entrepreneurial activities.

The key recommendations to the entrepreneurs living with physical disabilities include the following: Entrepreneurs living with physical disabilities have to intensify their confidence and invest in entrepreneurial education, since it aims at giving out knowledge, entrepreneurial skills and inspiration among entrepreneurs. Entrepreneurs living with physical disabilities need to conscious of entrepreneurial support schemes that are planned by the South African government; for example, the Small Enterprise Development Agency. It is recommended that entrepreneurs living with physical disabilities should acquire skills that will help to break the stereotypes and value systems that hinder them from participating in everyday activities with their able-bodied counterparts (Maziriri and Madinga, 2016; Kitching, 2014). It is 
imperative for entrepreneurs living with physical disabilities to engage in networking. 'Xesha, Iwu and Slabbert (2014)' are of the opinion that 'collaborative relationships enable the growth of businesses, as participants share information as well as other resources'. Therefore, entrepreneurs living with physical disabilities should form partnerships (business networks) with individuals from different areas of knowledge and expertise in order to learn from one another.

Limitations and future research: Although the findings offer valuable insights into the entrepreneurial barriers are confronted by entrepreneurs living with physical disabilities, this study is not exempted from its own limitations, which may affect future research. To start with, this study, being qualitative, had a limitation on the number of participants. The current study employed a small sample size of 35 participants. This restricts the researchers' ability to generalize the research findings of the study. In addition, this study has its limitation as participants are limited to entrepreneurs living with physical disabilities from only one particular South African Township. Therefore, future research could be done in a group with more respondents to understand the barriers better. Perhaps if data gathering is extended to take account of other regions and provinces of South Africa, this would strength the research findings. Therefore, future studies should consider this recommended research direction because the results of this study were limited as the study was conducted for a specific segment (entrepreneurs living with disabilities within the Sebokeng Township). Furthermore, there is also the problem of common method bias since qualitative research was purely used in this study. According to Maziriri and Madinga (2015), the descriptive nature of qualitative research has a bearing in that the biases, values and judgement of the researcher become stated explicitly in the research report. In other words, the researcher elucidates and interprets the results on the basis of what he or she has observed and uses this information to qualify and elucidate his or her point of view. For the study to be more robust, both qualitative and quantitative techniques had to be used. Moreover, all future research directions of this study will greatly complement new knowledge to the current body of literature.

\section{References}

Akanji, 0. O. (2006). Microfinance as a strategy for poverty reduction. Central Bank of Nigeria Economic and Financial Review, 39(4), 1-11.

Albrecht, G. L. (1997). Communities and families', in H.W. Wallace, J.C. MacQueen, R.F. Biehl \& J.A. Blackman (eds.). Mosby's resource guide to children with disabilities and chronic illness, 1, 13-20, Mosby electronic production, Missouri.

Antonites, A. \& Govindasamy, T. (2013). Critical success factors of Indian entrepreneurs. The Southern African Journal of Entrepreneurship and Small Business Management Journal, 6(1), 116-133.

Antonites, A. \& Kliphuis, W. (2011). An exploratory study on the potential value adds of social networking to the entrepreneurial process. The Southern African Journal of Entrepreneurship and Small Business Management, 4(1), 1-23.

Apolloni, L. (2010). Bringing about behaviour change: nursing practice and cardiac rehabilitation. Doctor of Public Health thesis, University of Wollongong. School of Health Sciences, University of Wollongong. Wollongong, New South Wales.

Babbie, E. \& Mouton, J. (2007). Qualitative methods of Data sampling. The practice of social research, 7, 187193.

Bakara, L. J. A., Mohamada, A., Abdullaha, S., Intan, N., Sulaimana, S. \& Hanafiaha, N. M. A. (2016). Entrepreneurial attitude of disabled people towards edu-tourism industry. Qualitative Research Conference (QRC), 24-26 May 2016, Penang, Malaysia. Viewed 12 November 2016, from http://qualitative-research-conference.com/qrc/download/proceedings2016/35\%20intan\%20saniah\%2098-104.pdf

Balfour, L. J. (2007). A needs assessment of parents on how to raise an autistic child, Master of Diaconiology thesis, University of South Africa, Pretoria.

Bongazana, H. (2014). Social influence as a determinant of conspicuous consumption among the South African Urban Township Youth. Acta Universitatis Danubius Administration, 6(2), 59-70.

Braun, V. \& Clarke, V. (2006). Using thematic analysis in psychology. Qualitative Research in Psychology 3, 77101. 
Budeli, M. C. (2012). Barriers and coping capacities experienced by people living with disability in the Nzhelele area of Limpopo province. Magister Artium thesis. (Unpublished Thesis). University of Johannesburg, Johannesburg.

Burger, L., Mahadea, D. \& Neill, C. O. (2004). Perceptions of entrepreneurship as a career option in South Africa: an exploratory study among grade 12 learners. South African Journal of Economic and Management Sciences, 7(1), 187-205.

Certo, S. T., Moss, T. W. \& Short, J. C. (2009). Entrepreneurial orientation: An applied perspective. Business Horizons, 52(4), 319-324.

Chell, E., Spence, L. J., Perrini, F. \& Harris, J. D. (2016). Social Entrepreneurship and business ethics: Does social equal ethical? Journal of Business Ethnics, 133, 619-625.

Chimucheka, T. \& Mandipaka, F. (2015). Challenges faced by small, medium and micro enterprises in the Nkonkobe Municipality. International Business \& Economics Research Journal, 14(2), 309-316.

Chimucheka, T. (2014). Entrepreneurship education in South Africa. Mediterranean Journal of Social Sciences, $5(2), 403-416$.

Chinomona, E. \& Maziriri, E. (2015). Examining the phenomenon of xenophobia as experienced by African immigrant entrepreneurs in Johannesburg, South Africa: Intensifying the spirit of Ubuntu. International Journal of Research in Business Studies and Management, 2(6), 20-31.

Chinomona, E. \& Maziriri, E. T. (2015). Women in action: Challenges facing women entrepreneurs in the Gauteng province of South Africa. The International Business \& Economics Research Journal, 14(6), 835-850.

Chinomona, E., Maziriri, E. \& Moloi, K. C. (2014). Corporate entrepreneurship with innovation in mind in one University of Technology in South Africa. Mediterranean Journal of Social Sciences, 5(23), 20-29.

Choto, P., Tengeh, R. K. \& Iwu, C. G. (2014). Daring to survive or to grow? The growth aspirations and challenges of survivalist entrepreneurs in South Africa. Environmental Economics, 5(4), 93-101.

Cooke, M. (2009). Children's experience of their obesity. Master of Diaconiology Thesis. University of South Africa. Pretoria.

Cooper, D. R. \& Schindler, P. S. (2011). Business research methods, 11th edn., McGraw-Hill, Singapore.

Creswell, J. W. \& Plano, C. V. L. (2007). Designing and conducting mixed methods research, Sage, Thousand Oaks, CA.

Dahlberg, L. \& Mccaig, C. (2010). Practical research and evaluation: A start-to-finish guide for practitioners, Sage, London.

Dawson, C. \& Henley, A. (2012). Push versus "Pull" entrepreneurship: An ambiguous distinction? International Journal of Entrepreneurial Behaviour \& Research, 18(6), 697-719.

Dijkhuizen, J., Gorgievski, M., Van Veldhoven, M. \& Schalk, R. (2016). Feeling successful as an entrepreneur: A job demands-resources approach. International Entrepreneurship and Management Journal, 12(2), 555-573.

Dotson, W., Richman, D., Abby, L. \& Thompson, S. (2013). Teaching skills related to self-employment to adults with developmental disabilities: An analog analysis. Research in Developmental Disabilities, 34(1), 2336-2350.

Dube, B., Roberts-Lombard, M. \& van Tonder, E. (2015). Management guidelines for universal quality challenges across the focus group research process. Journal of Applied Business Research, 31(1), 239247.

Duvenhage, A. (2013). Risk Taking Patterns of Entrepreneurs in Roodepoort. Master of Business Administration Thesis. Tshwane University of Technology. Pretoria.

Edelman, L. F., Manolova, T., Shirokova, G. \& Tsukanova, T. (2016). The impact of family supports on young entrepreneurs' start-up activities. Journal of Business Venturing, 31(4), 428-448.

Enabled4Enterprise. (2008). Barriers and opportunities: Equipping the enterprise sector to deliver 'disability smart' services, viewed 20 May 2015, from http://www.lcdisability.org/?lid=19899

Falch, R. \& Hernæs, U. J. V. (2012). Disability, social identity, and entrepreneurship: Evidence from a laboratory experiment in rural Uganda, Master thesis in Economics, Norwegian School of Economics, Bergen, Norway.

Farrington, S. M., Vender. D. J. L., Schrage, C. R. \& Van der Meer, P. O. (2012). Entrepreneurial attributes of undergraduate business students: A three country comparison revisited. South African Journal of Economic and Management Sciences, 15(4), 333-351. 
Fatoki, O. \& Chindoga, L. (2011). An Investigation into the obstacles to youth entrepreneurship in South Africa. International Business Research, 4(2), 161-169.

Fatoki, O. \& Garwe, D. (2010). Obstacles to the growth of new SMEs in South Africa: A principal component analysis approach. African Journal of Business Management, 4(5), 729-738.

Fatoki, O. (2014). Immigrant entrepreneurship in South Africa: Current literature and research opportunities. Journal of Social Sciences, 40(1), 1-7.

Fatoki, O. (2014). Factors Influencing the Financing of Business Start-ups by Commercial Banks in South Africa. Mediterranean Journal of Social Sciences, 5(20), 94-100.

Fatoki, 0. 0. (2010). Graduate entrepreneurial intention in South Africa: Motivations and obstacles. International Journal of Business and Management, 5(9), 87-98.

Flyvbjerg, B. (2011). Case study, in N.K. Denzin \& Y.S. Lincoln (eds.). The SAGE handbook of qualitative research, 4th edn., pp. 301-316, Sage, Thousand Oaks, CA.

Foster, S. (2010). Promoting entrepreneurship among disabled people with visual impairment, viewed 15 May 2015, from http://www.heacademy.ac.uk

Glesne, C., (2011). Becoming qualitative researchers: An introduction, 4th edn., Pearson Education, Boston, MA.

Gorora, G. P. K. \& Mago, S. (2013). Challenges of rural entrepreneurship in South Africa: insights from nkonkobe municipal area in the Eastern Cape Province. International Journal of Information Technology and Business Management, 16(1), 1-11.

Gree, A. \& Thurnik, C. (2003). Firm selection and industry evolution: the post country performance of new firm. Journal of Evolutionary Economics, 4(4), 243-264.

Greeff, M. (2005). Information collection: Interviewing', in A.S. De Vos, H. Strydom, C.B. Fouché \& C.S.L. Delport (eds.), Research at grass roots: For the social services and human service professions, 3rd edn., pp. 286-313, Van Schaik Publishers, Pretoria.

Greve, B. (2009). The Labour Market Situation of Disabled People in European Countries and Implementation of Employment Policies: A Summary of Evidence from Country Reports and Research Studies, Report prepared for the Academic Network of European Disability experts (ANED). Viewed 13 August 2016 from http://www.disabilityeurope.net.

Hammond, M., Howarth, J. \& Keat, R. (1991). Understanding phenomenology, Basil Blackwell, Oxford.

Hefer, Y., Cant, M. C. \& Wiid, J. A. (2015). Starting one's own business - What motivates entrepreneurs? International Business \& Economics Research Journal, 14(2), 237-246.

Henderson, J. (2002). Building the rural economy with high-growth entrepreneurs. Economic Review Federal Reserve Bank of Kansas City. Economic Review, 87(3), 45-70.

Herrington, M. \& Wood, E. (2003). Global entrepreneurship monitor, South African report, viewed 25 May 2015, from http://www.gbs.nct.ac.za/gbswebb/userfiles/gemsouthafrica2000pdf

Hessels, J., Gelderen, M. \& Thurik, R. (2015). Entrepreneurial aspirations, motivations, and their drivers. Small Business Economics, 31(3), 323-339. ht

Hisrich, R. D. \& Peters, M. P. (2002). Entrepreneurship. International 5th Edition. McGraw Hill/ Irvin; Higher Education.

Isaacs, E., Visser, K., Friedrich, C. \& Brijlal, P. (2007). Entrepreneurship education and training at the Further Education and Training (FET) level in South Africa. South African Journal of Education 2(7), 613-629.

Johnmark, D. R. \& Munene, J. (2016). Discrimination in predicting entrepreneurial intentions of the disabled students in Nigeria. International Journal of Managerial Studies and Research, 4(1), 1-13.

Kasperova, E. (2011). Entrepreneurship identity, disability, and embodiment, Small Business Research Centre, Kingston Business School, London.

Keene, S. (2011). Social bias: Prejudice, stereotyping, and discrimination. The Journal of Law Enforcement, 1(3), 1-5.

Khosa, R. M. \& Kalitanyi, V. (2014). Challenges in operating micro-enterprises by African foreign entrepreneurs in Cape Town, South Africa. Mediterranean Journal of Social Sciences, 5(10), 205-215.

Kitching, J. (2014). Entrepreneurship and self-employment by people with disabilities', Background paper for the OECD Project on Inclusive Entrepreneurship, Kingston University, Kingston, England.

Leedy, P. D. \& Ormrod, J. E. (2010). Practical research: Planning and design, 9th edn., Prentice Hall, Upper Saddle River, NJ.

Lord, J. A. (2009). Identification of a dominant defence mechanism for children in their middle childhood in dealing with fear. Master of Diaconiology Thesis. University of South Africa. Pretoria. 
Ngorora, G. P. K. \& Mago, S. (2013). Challenges of rural entrepreneurship in South Africa: insights from nkonkobe municipal area in the Eastern Cape Province. International Journal of Information Technology and Business Management, 16(1), 1-11.

Maas, G. \& Herrington, M. (2006). Global entrepreneurship monitor South Africa report. Viewed 12 November 2016, from http://www.gemconsortium.org/document.aspx?id756

Makhbul, Z. M. \& Hasun, F. M. (2011). Entrepreneurial success: an exploratory study among entrepreneurs. International Journal of Business and Management, 6(1), 116-125.

Maja, P. A., Mann, W. M., Sing, D., Steyn, A. J. \& Naidoo, P. (2011). Employing people with disabilities in South Africa. South African Journal of Occupational Therapy, 41(1), 24-32.

Mandipa, E. (2013). Critical analysis of the legal and institutional frameworks for the realization of the rights of persons with disabilities in Zimbabwe, in C. Ngwena, I. Grobbelaar-du Plessis, H. Combrinck \& S.D. Kamga (eds.), African disability rights year book, vol. 1, pp. 73-96, Pretoria University Law Press, Pretoria.

Mandipaka, F. (2014). An investigation of the challenges faced by women entrepreneurs in developing countries: A case of King Williams' Town, South Africa. Mediterranean Journal of Social Sciences, 5(27), 1187-1193.

Marino, E., González, J., López, J., Luján, J., Gordillo, M. \& Osorio, C., (2011), 'Science, technology and society: A conceptual approximation. Notebooks of Latin America, 1(1), 10-25.

Martins, S. \& Couchi, C. (2004). Barriers to entrepreneurship and business creation. Arouca, Portugal: European Entrepreneurship Cooperation. Viewed 12 November 2016, from http://webcache.googleusercontent.com/search?q=cache:1q9qAOdqzTIJ:

Marumoagae, M. C. (2012). Disability discrimination and the right of disabled persons to access the labour market. Potchefstroom Electronic Law Journal, 15(1), 345-428.

Masitha, H. (2001). The prevalence of post-traumatic stress disorder (PTSD) in school children in a black township, MA thesis, The University of the Witwatersrand, Johannesburg.

Mauchi, F. N., Mutengezanwa, M. \& Damiyano, D. (2014). Challenges faced by women entrepreneurs: A case study of Mashonaland Central Province. International Journal of Development and Sustainability, 3(3), 466-480.

Mazibuko, L. A. (1993). The value - Orientations and perceptions of Zulu secondary school pupils in sebokeng, Master of Education, Randse Afrikaanse Universiteit, Johannesburg.

Maziriri, E. T. \& Madinga, N. W. (2015). The Effect of buyer's remorse on consumer's repeat-purchase intention: Experiences of Generation Y apparel student consumers within the Vaal Triangle. International Journal of Research in Business Studies and Management, 29(5), 24-31.

Maziriri, E. T. \& Madinga, N. W. (2016). A Qualitative Study on the Challenges Faced by Entrepreneurs Living with Physical Disabilities within the Sebokeng Township of South Africa. International Journal of Research in Business Studies and Management, 3(5), 1-13.

Mccann, P. \& Ortega-Argiles, R. (2016). Smart specialization, entrepreneurship, and SMEs: Issues and challenges for a results-oriented EU regional policy. Small Business Economic Journal, 46(1), 537-552.

Mdluli, P. G. (2015). The relationship between household poverty and child deprivation in Jabulani Township', Magister Commercii (Economics), North-West University, Vaal Triangle Campus, Vanderbijlpark.

Mersland, R. (2005). Microcredit for self-employed disabled persons in developing countries. Oslo, Norway: Atlas Alliance.

Mohammed, A. U. \& Jamil, S. A. (2015). Entrepreneurial barriers faced by disabled in India. Asian Social Science Journal, 11(24), 72-78.

Moloi, K. C., Dzvimbo, K. P., Potgieter, F. J., Wolhuter, C. C. \& VanderWalt, L. J. (2010). Learner's perceptions as to what contributes to their school success: A case study. South Journal of Education, 30, 475-490.

Morales, T. C. P., Ferie, C. P., Fonseca, F. \& Frias, R. (2016). The entrepreneurship of the young population in the Ecuadorian context, showing the approach of the science, technology, and society. Journal of Service Science and Management, 9(1), 28-35.

Moyo, C. S. \& Francis, J. (2010). Women empowerment initiatives for rural development in South Africa: The missing piece of the puzzle. Pula: Botswana Journal of African Studies, 24(1), 43-63.

Mpofu, J. \& Shumba, A. (2013). Disabilities and entrepreneurship in Makonde rural community in Zimbabwe. Stud Tribes Tribal, 11(2), 135-144. 
Mpofu, J., Gasva, D., Gwembire, J. \& Mubika, D. (2011). Introduction to special needs education, Zimbabwe Open University, Harare.

Muposhi, A. (2015). Green consumer buying behaviour: Antecedents, selection attributes of generation y consumers and the relationship with future behavioural intentions. Doctor of Technology Thesis. Vaal University of Technology. Vanderbijlpark.

Muposhi, A., Dhurup, M. \& Surujlal, J. (2015). The green dilemma: Reflections of a generation y consumer cohort on green purchase behaviour. The Journal for Trans-disciplinary Research in Southern Africa, 11(3), 225-240.

Mwangi, M. W. (2013). Factors that affect the success of physically challenged entrepreneurs in their business activities: A survey of Thika municipality - Kiambu County, Kenya Margaret Wanjiku Mwangi. International Journal of Academic Research in Business and Social Sciences, 3(1), 280-289.

Ncanywa, N. A. (2014). The identification of factors contributing to the vulnerability to sexual abuse of orphans in a rural area, Master of Social Work in Forensic Practice dissertation. North-West University. Potchefstroom

Nchu, R. M., Tengeh, R. K. \& Hassan, S. (2015). High school learner's perception of the efficacy of entrepreneurship education: The case of selected high schools in the Western Cape, South Africa. The Scientific Journal of Theory and Practice of Socio-economic Development, 4(8), 507-526.

Oates, J., Kwiatkowski, R. \& Coulthard, L. M. (2010). Code of human research ethics. The British Psychological Society 4(1), 5-30.

Obaji, N. O. \& Olugu, M. U. (2014). The role of government policy in entrepreneurship development. Science Journal of Business and Management, 2(4), 109-115. 2

Obaji, N. O. \& Olugu, M. U. (2014). The role of government policy in entrepreneurship development. Science Journal of Business and Management, 2(4), 109-115.

Oni, E. O. \& Daniya, A. (2012). Development of small and medium scale enterprises: The role of government and other financial institutions. Arabian Journal of Business and Management Review, 1(7), 16-29.

Osman, C. A., Rahim H. L., Yusof, M. M., Zikrul, M., Noor, H. \& Lajin, N. F. M. (2014). Empowering disabled youth with entrepreneurial values. in 2nd Asian Entrepreneurship Conference Proceeding, Singapore, December 18, 2015.

Parhankangas, A. \& Ehrlich, M. (2014). How entrepreneurs seduce business angels: An impression management approach. Journal of Business Venturing, 29(4), 543-564.

Parker, H. S., Caldwell, K. \& Renko, M. (2014). Entrepreneurship by any other name: Self-sufficiency versus innovation. Journal of Social Work in Disability \& Rehabilitation, 13(4), 1-33.

Parker, H. S., Renko, M. \& Caldwell, K. (2013). Accessing social entrepreneurship: Perspectives of people with disabilities and key stakeholders. Vocational Rehabilitation, 38, 35-48.

Pergelova, A. \& Angulo-Ruiz, F. (2014). The impact of government financial support on the performance of new firms: the role of competitive advantage as an intermediate outcome. Entrepreneurship \& Regional Development, 26(9-10), 663-705.

Physical Disability Council. (2015). Physical disability, viewed 14 May 2015, from http://www.pdcsa.org.au/

Pivcevic, E. (1970). Husserl and phenomenology, Hutchinson University Library, London.

Rahim, H. L., Abidin, Z. Z., Ping, S. D. S., Alias, M. K. \& Muhamad, A. I. (2014). Globalization and its effect on world poverty and inequality. Global Journal of Management and Business, 1(2), 09-13.

Raposo, M. \& Do Paço, A. (2011). Entrepreneurship education: Relationship between education and entrepreneurial activity. Psicothema, 23(3), 453-457.

Renko, M., Harris, S. P. \& Caldwell, K. (2015). Entrepreneurial entry by with disabilities', International Small Business Journal, 33(3), 231-348.

Retief, F. J. (2009). The contribution of Appreciative Inquiry on the attitudes of church members towards a change in strategic focus. Master of business administration thesis. Management College of Southern Africa. Durban.

Robbins, S. P., Chatterjee, P. \& Canda, E. R. (1998). Contemporary human behavior theory: A critical perspective for social work, Allyn and Bacon, Boston, MA.

Roets, C. R. Q. (2013). Black generation y students' attitudes towards the de-marketing of smoking and alcohol consumption, Masters dissertation in Marketing Management, North-West University, Vaal Triangle, Vanderbijlpark.

Roni, N. N. \& Baines, S. (2012). Why Entrepreneurship Process as a Battle for Business Resources Recognition for Disadvantaged People? Journal of Business Studies, 33(1), 55-90. 
Roni, N. N. (2009). Disabled entrepreneurship: A viable route of opportunity for the disabled. Doctoral Symposium. Manchester Metropolitan University. Manchester.

Rueedi, F. (2015). Siyayinyova! Patterns of violence in the African townships of the Vaal Triangle, South Africa, 1980-86. The Journal of International African Institute, 85(3), 395416.http://dx.doi.org/10.1017/S0001972015000261

Sale, J., Lohfeld, L. \& Brazil, K. (2002). Revisiting the quantitative-qualitative debate: Implications for mixed methods. Quality and Quantity, 36(1), 43-53.

Salem, M. I. (2014). The role of business incubators in the economic development of Saudi Arabia. International Business and Economics Research Journal, 13(4), 853-860.

Salkind, N. J. (2012). Exploring research, Pearson, Boston, MA.

Sauer, R. M. \& Wilson, T. (2016). The rise of female entrepreneurs. European Economic Review, 86(1), 73-86.

Sebokeng Map. (2016). The Sebokeng Township, viewed 23 July 2016, from https://www.google.co.za/maps/place/Sebokeng

Sefotho, M. M. (2015). A researcher's Dilemma: Philosophy in crafting dissertations and theses. Journal of Social Sciences, 42(1), 23-36.

Shanimon, S. \& Hameedu, M. S. (2014). The emerging development model in India differently-abled entrepreneurs. International Journal of Scientific and Research Publications, 4(1), 1-11.

Show me South Africa. (2016). Sebokeng Township, viewed 22 July 2016, from http://showme.co.za/vaal/tourism/sebokeng

Shuma, T. W. (2011). Experiences of people with physical disabilities who participate in the community based rehabilitation (CBR) programme in Okamatapati community, Otjozondjupa Region, Masters dissertation in Public Health, University of Namibia, Windhoek.

Sobuce, N. W. (2012). Waste Recycling and Small, Micro, and Medium Enterprises (SMMEs) Development in Greater Kokstad Municipality. Master of Arts (Social Development) dissertation, Faculty of Humanities, School of Human and Community Development, University of the Witwatersrand. Johannesburg.

Statistics South Africa. (2015). Prevalence of disability, viewed 14 May 2015, from http://www.statssa.gov.za/?p=3180

Steenekamp, A. G., VanderMerwe, S. P. \& Athayde, R. (2011). An investigation into youth entrepreneurship in selected South African secondary schools: An exploratory study. Southern African Business Review, 15(3), 46-75.

Stofberg, R. (2009). Employers' attitudes and experiences regarding employees with intellectual disability, Master of Diaconiology Thesis. University of South Africa. Pretoria.

Stokes, D., Wilson, N. \& Mador, M. (2010). Entrepreneurship. South Western, Centage Learning.

Strydom, H. (2005). Ethical aspects of research in the social sciences and human services professions. 56-70, in A.S. De Vos, H. Strydom, C.B. Fouche, C.S.L. Delport (eds.). Research at Grass Roots: For the social services and human service professions. (3rd edition). Pretoria: Van Schaik Publishers

Taylor, M. C. (2005). Interviewing. In I. Holloway (Ed.), Qualitative Research in Health Care, Open University Press, England.

Tehseen, S. \& Ramayah, T. (2015). Entrepreneurial competencies and SMEs business success: The Contingent role of external integration. Mediterranean Journal of Social Sciences, 6(1), 50-61.

Thompson, C., Bounds, M. \& Goldman, G. (2012). The status of strategic planning in Small and Medium Enterprises: Priority of afterthought? The Southern African Journal of Entrepreneurship and Small Business Management, 5(1), 34-53.

Uromi, S. M. \& Mazagwa, M. I. (2015). Challenges facing people with disabilities and possible solutions in Tanzania. Journal of Educational Policy and Entrepreneurial Research, 1(2), 158-165.

Van der Lingen, E. \& Van Niekerk, G. (2015). Entrepreneurship Traits of Science, Engineering and Technology (SET) Students. The Southern African Journal of Entrepreneurship and Small Business Management, $7(1), 117-144$.

Viriri, P. \& Makurumidze, S. (2014). Engagement of disabled people in entrepreneurship programmes in Zimbabwe. Journal of Small Business and Entrepreneurship Development, 2(1), 1-30.

Vlachou, A. D. (1997). Struggle for inclusive education - An ethnographic study, Open University Press, Buckingham. 


\section{Journal of Economics and Behavioral Studies (ISSN: 2220-6140)}

Vol. 9, No. 1, pp. 27-45, February 2017

Wairimu, G. J. (2014). Relevance of vocational courses for trainees with physical disabilities to market demands at Muriranjas and Nyandarua centres, Murang'a and Nyandarua counties, Kenya, Doctoral dissertation, Kenyatta University, Nairobi City, Kenya.

Welman, C., Kruger, F. \& Mitchell, B. (2011). Research methodology, 3rd edn., Oxford University Press, Cape Town.

Whitley, B. E. (2002). Principles of Research in Behavioral Science. New York: McGraw-Hill.

Wilson, B. (2016). The labour market situation of disabled people in European Countries and implementation of employment policies: A summary of evidence from country reports and research studies, Report prepared for the Academic Network of European Disability experts (ANED), viewed 10 May 2015, from http://www.disabilityeurope.net

Wongnaa, C. A. \& Seyram, A. Z. K. (2014). Factors influencing polytechnic students' decision to graduate as entrepreneurs. Journal of Global Entrepreneurship Research, 2(1), pp.1-13.

Xaba, G. M. \& Rankhumise, E. M. (2014). Business owners' perspectives in pursuance of their businesses: what matters most? Problems and perspectives in management, 12(2), 181-189.

Xesha, D., Iwu, C. G. \& Slabbert, A. (2014). Business relationships as a driver of success for small, medium, and micro enterprises (SMMEs) in South Africa. Journal of Economics, 5(1), 37-43.

Yamamoto, S., Unruh, D. \& Bullis, M. (2015). The viability of self-employment for individuals with disabilities in the United States: A synthesis of the empirical-research literature. Journal of Vocational Rehabilitation, 35(2), 117-127. 